\title{
Identification and Prioritization of Major Factors that Challenge Crop Productivity and Production System in the Case of Gamo Gofa, Segen Area People Zone and Basketo Special Woreda
}

\author{
Tariku Simion*, Getachew Gudero, Kanko Chuntale, Alemnesh Ayza, Abriham Alemu, Arega Abebe and \\ Abayneh Fayso \\ South Agricultural Research Institute, Arbaminch Agricultural Research Center, Ethiopia
}

Submission: March 10, 2018; Published: April 27, 2018

"Corresponding author: Tariku Simion, Crop research process coordinator at Agricultural research institute, Southern Agricultural Research Institute, Haramaya University, Ethiopia, Email: trk2011smn@gmail.com

\begin{abstract}
Agriculture employs more than 84 percent and contributes 30-60\% of the gross domestic product (GDP) in Ethiopia. Agriculture output also is used as an input for industries and can stimulate the growth of industrialization. In SNNPR, $90 \%$ of the total population depends on agriculture as a source of cash income, home consumption, as industry inputs and for export purpose. This survey was conducted at Gamogofa, Segen Area People Zones and Basket Special Woreda by Arbaminch Agricultural Research Center to identify and prioritize major factors that challenge crop production and productivity and to meet the demand and need of stakeholders, markets and end users in the study areas. Formal and informal data sources were used to generate information. Lack of improved crops varieties and associated improved management and protection practices were some of the major constraints that were identified and needs attention for further research solutions in the crop production systems.
\end{abstract}

Keywords: Production; Study; Prioritize; Special; Challenge

\section{Introduction}

Agriculture, generally in Ethiopia and specifically in SNNPR, is the leading sector as source of income, employment and foreign exchange and national economic growth is determined by the performance of agriculture. Agriculture employs more than 84 percent and contributes 30 to $60 \%$ of the gross domestic product (GDP) [1]. Agriculture output also is used as an input for industries so it can stimulate the growth of industrialization. In SNNPR, 90 percent of the total population depends on agriculture as a source of cash income, home consumption, as industry inputs and for export purpose.

The survey report which was jointly conducted by Southern Agricultural Research Institute (SARI) and Bureau of [2] shows that the yield was too low in most crop cultivars (unpublished, 2008). To resolve these specific agricultural productivity constraints, several works have been done across the country. Massive movement to test suitability of the existing technologies on different crops has been carried out in different agro-ecologies and the best technologies were pre-scaled up in some localities. To advance improvement of crop productivity in different localities, continual identification of the best and suitable crop technologies appeared to be essential.
Arbaminch Agricultural Research Center is one of six research centers under Southern Agricultural Research Institute. It is established in 2004 E.C at Arbaminch town which is $495 \mathrm{~km}$ far from Addis Ababa, capital of Ethiopia. Adaptation, demonstration, technology development and Innovation, promotion, and technology multiplication is key activities of the center to improve livelihood, income, life system, and to insure food security of farming communities and to able small holder farmers to produce quality import substitution and export commodities [3].

Research focused areas of GTP-II are, demandable for export and import substitution, food security, commercial, home consumption and local market crops. Arbaminch Agricultural Research Center Crop research Process team has been conducted formal and informal survey to identify and prioritize key problems and constraints related with aforementioned purpose crop production and marketing system in the mandate area of the research center, i.e. Gamogofa and Segen area peoples zones and Basketo special woreda. Key crops produced in the mandate area are Cereals, Pulses, fiber, oils, and coffee, spices and Horticultural crops. Accordingly for the purpose of research 
inputs for GTP-II and for further research actions, there was no any generated information that shows direction for further research intervention in the area so far. Therefore, this survey was initiated with the following objectives:

a) To identify, prioritize and generate information about crop production problems in the mandate areas for further research action.

b) To meet the demands and needs of stakeholders, markets and end users.

\section{Methodology}

\section{Description of study area}

Gamo gofa zone is one of 14zones' of SNNPR and its capital, Arbaminch is located $495 \mathrm{~km}$ in South direction from Addis Ababa. The zone has 14woredas, each woreda has three ecological zones; viz: highland (35\%), lowland (39.1\%) and mid (moderate) (26\%) climatic zone. Around 92\% populations' livelihood is dependent on agriculture for both home consumption and income generation. The main cash crop of the zone includes: sesame, banana, coffee, kororima, apple, and mango. Tef, maize, barley, wheat, faba bean, field pea, and haricot bean are cultivated for both cash and home consumption. Weaving, pottery and small scale trade are off-farm activities of the zone (unpublished, 2010).

Segen peoples zone is one of 14 zones of SNNPR which has been established on [4], its capital, Segen is $645 \mathrm{~km}$ far from Addis Ababa, the capital of Ethiopia and $342 \mathrm{~km}$ far from Hawassa, the capital of SNNPR; which has five woredas viz: Dereshe, Konso, Allie, Burji and Amaro woredas with three agro-ecological zones namely: high, mid and low land, which covers $22.9 \%, 36.084 \%$, $41.122 \%$ respectively. Temperature of the zone ranges from 13.54-25.88 degree centigrade and its mean annual temperature is 19.7 degree centigrade. Rainfall distribution of the zone ranges from $700-1025 \mathrm{~mm}$. Altitudinal location of the zone ranges from 500 meter, Segen Sawate which is found in Konso woreda to 3600 meter high land area, Delo Mountain which found in Amaro woreda. Land features of the zone comprises of $34 \%$ plane, $53.25 \%$ plateau, $12.75 \%$ Mountain, with total area of 751,932 hectare; from this arable land covers 221,245.9 hectare, range land covers $36,247.4$ hectare, forest land covers $305,277.8$ hectare, 7043.6 hectare can be cultivated by irrigation (unpublished, 2010).

Basketo special woreda is one of the four special woredas of South Nation Nationalities and People Regional State, its capital; Laska is $626 \mathrm{~km}$ far from Addis Ababa, the capital of Ethiopia. Temperature of the special woreda ranges from 15 ${ }^{\circ} \mathrm{C}-27{ }^{\circ} \mathrm{C}$ and its mean annual rainfall ranges from $1000 \mathrm{~mm}$ $1400 \mathrm{~mm}$. Altitudinal location of the special woreda ranges from $780-2200 \mathrm{~m}$ a.s.l. The special woreda has three ecological zones; viz: highland (1\%), lowland (54\%) and mid (45\%) climatic zone (unpublished, 2010).

\section{Methods}

Pulse and oil, coffee and spices, and horticultural crops were identified for further research directions. The survey was conducted in Gamogofa and Segen area people zones (selected woredas) and Basketo Special woreda in southern nations, nationalities and people's regional state (SNNPR). Primary and secondary data were used to generate information for further research interventions. Primary data were collected through discussion with corresponding farmers. Information particularly crop production and related constraints were identified and summarized. Major factors that hinder production and productivity of key crops like Cereal

\section{Result and Discussions (Table 1)}

Table 1: Agronomic practices and farming system for sorghum.

\begin{tabular}{|c|c|c|c|c|c|}
\hline \multirow[t]{2}{*}{ Crop } & \multicolumn{2}{|c|}{ Cultivars } & \multicolumn{2}{|c|}{$\begin{array}{l}\text { Cropping Calendar } \\
\text { (Including Land } \\
\text { Preparation) }\end{array}$} & \multirow[t]{2}{*}{$\begin{array}{c}\text { Agro } \\
\text { Ecology }\end{array}$} \\
\hline & Improved & Local & Belg & Meher & \\
\hline Sorghum & $\begin{array}{l}\text { Teshale, } \\
\text { Abshir, } \\
\text { Gobiye, } \\
\text { Birmash } \\
\text { and } \\
\text { Gambela }\end{array}$ & $\begin{array}{c}\text { Bichita, } \\
\text { Aylelta, } \\
\text { Shulayta, } \\
\text { Godano, } \\
\text { Moroto, } \\
\text { Bicha, } \\
\text { Karteta } \\
\text {,Tanga, } \\
\text { Rara, } \\
\text { Konado }\end{array}$ & $\begin{array}{c}\text { Tir } \\
\text {-Megebit }\end{array}$ & $\begin{array}{l}\text { Hamile } \\
\text {-Tikimt }\end{array}$ & $\begin{array}{l}\text { Low and } \\
\text { mid land }\end{array}$ \\
\hline
\end{tabular}

Some important traits of local cultivars includes; maturity period (Bichita, Aylelta and Shulayta takes six months for maturity. Cultivars with five month for maturation include Moroto and Karteta. Cultivars with four month for maturation include Godano and cultivars with 12 month for maturation include Tanga and Bicha. Bicha, Bichita, Aylelta and Shulayta gives better yield after cutting-off first vegetative part (rejuvenation), if there is sufficient rainfall. There is no trend of fertilizer application. Hand weeding is major mechanism of crop management with frequency of 2-3 times $\left(1^{\text {st }} 25\right.$ days after planting, $2^{\text {nd }} 40$ days after planting and $3^{\text {rd }} 80$ days after planting). Leaf blights, gray leaf spot, rough leaf spot, head smut, downy mildew, stalk, root, head and seedling diseases, rust, sorghum anthracnose are major diseases at the study area where as sorghum shoot fly, stalk borer, cut worm, red ant, flea beetle, white fly and stink bugs are major insect pests. Challenges that were identified for further research action includes lack of low moisture resistance, early maturing and high yielding varieties, existence of noxious weed (striga), Poor agronomic practices, food science, lack of awareness on economic and nutritional value of the crop, low cost and market demand that forces farmers not to give attention for the production. Major Sorghum growing areas of the study: Konso, Derashe, Zala, Kamba, Oyda, Dembagofa, Basketo special woreda, Ubadebretsehay, Alle (Table 2). 
Annals of Social Sciences \& Management studies

Table 2: Agronomic practices and farming system for maize.

\begin{tabular}{|c|c|c|c|c|c|}
\hline \multirow[t]{2}{*}{ Crop } & \multicolumn{2}{|l|}{ Cultivars } & \multicolumn{2}{|c|}{$\begin{array}{l}\text { Cropping Calendar } \\
\text { (Including Land } \\
\text { Preparation) }\end{array}$} & \multirow[t]{2}{*}{ Agro Ecology } \\
\hline & Improved & Local & Belg & Meher & \\
\hline Maize & $\begin{array}{l}\text { Low land varities: BH-140, BH-540, Shala, Lemu, Shone, Jabi mid land } \\
\text { varieties: BH-540, BH-140 and high land varities :- BH-660 and Agar }\end{array}$ & No & $\begin{array}{l}\text { Hidar- } \\
\text { Miyaziya }\end{array}$ & $\begin{array}{l}\text { Hamile- } \\
\text { Nehasie }\end{array}$ & $\begin{array}{l}\text { Low, mid } \\
\text { land, and high } \\
\text { land }\end{array}$ \\
\hline
\end{tabular}

Maize lethal Necrosis Virus (MLNV), Leaf rust, leaf blotch, leaf blight, ear rot, root rot, fusarium wilt, head smut, sterility (BH540 and Shone), red streak are major identified diseases in the area. Major insect pests include black cutworm, flea beetle, stalk borer, armyworm, root worm, ear worm/cob borer and aphid. Major constraints in maize production areas are lack of improved varieties available for appropriate agro-ecology, poor agronomic Table 3: Agronomic practices and farming system for millet.

\begin{tabular}{|c|c|c|c|c|c|}
\hline Crop & \multicolumn{2}{|c|}{ Cultivars } & \multicolumn{2}{c|}{$\begin{array}{c}\text { Cropping Calendar (Including Land } \\
\text { Preparation) }\end{array}$} & Agro Ecology \\
\hline & Improved & Local & Belg & Meher & \\
\hline Millet & No & Two cultivars with Black and red seed color & Tir - Megebit & Hamile -Tikimt & Low and mid land \\
\hline
\end{tabular}

Table 4: Agronomic practices and farming system for wheat.

\begin{tabular}{|c|c|c|c|c|c|}
\hline \multirow[t]{2}{*}{ Crop } & \multicolumn{2}{|l|}{ Cultivars } & \multicolumn{2}{|c|}{$\begin{array}{c}\text { Cropping Calendar } \\
\text { (Including Land Preparation) }\end{array}$} & \multirow[t]{2}{*}{ Agro Ecology } \\
\hline & Improved & Local & Belg & Meher & \\
\hline wheat & $\begin{array}{c}\text { Semba, Dendea, Et-13A, Degalu(HAR-3116), picalora, Hidase, } \\
\text { Huluka, Shorima, Galma, (HAR-604), WETERA(HAR-1920), } \\
\text { HAR-1685, Kubsao and HAR-710 }\end{array}$ & $\begin{array}{l}\text { Beshkela used } \\
\quad \text { for tella }\end{array}$ & - & $\begin{array}{l}\text { Ginbot- } \\
\text { Nehase }\end{array}$ & Low and mid land \\
\hline
\end{tabular}

There is no sole production system of millet, rather it is mixed with sorghum and sown by broadcast in the same field simultaneously at a time. Lack of awareness about the importance of the crop and lack of improved technologies (varieties and agronomic practice) are major constraint in the area (Table 4).

Bread wheat growing area under the mandate area of the center includes Chencha, Bonke ,Geze Gofa, Mello koza , Basketo special woreda, Oyda, Ubadebretseha, Kamba. Major diseases include; wheat stem rust, wheat leaf/brown rust, wheat yellow/ stripe rust, loose smut, head blight/head scab, powdery mildew, septoria blotches, common bunt, common root rot and scab, eye spot (foot rot, straw-breaker), tan spot (yellow leaf spot), spot blotch, take bacterial stripe and black chaff. Major Insect pests include aphid, russian wheat aphid, brown wheat Mite, rose grain aphid, wheat stem maggot, stink bugs, grasshoppers, armyworms, termite, black fly and beetle.

Table 5: Agronomic practices and farming system for barley.

\begin{tabular}{|c|c|c|c|c|c|}
\hline \multirow[t]{2}{*}{ Crop } & \multicolumn{2}{|r|}{ Cultivars } & \multicolumn{2}{|c|}{$\begin{array}{l}\text { Cropping Calendar } \\
\text { (Including Land } \\
\text { Preparation) }\end{array}$} & \multirow[t]{2}{*}{$\begin{array}{c}\text { Agro } \\
\text { Ecology }\end{array}$} \\
\hline & Improved & Local & Belg & Meher & \\
\hline Barley & HB - 1307 & $\begin{array}{l}\text { Ocho (blackcolored), Solga (white colored seed), Daro (greenish } \\
\text { colored seed), Hunche, Addea banga Maste, Wolate, Zefo, Santala } \\
\text { (used for medicinal purpose) and Mume murqa. }\end{array}$ & $\begin{array}{l}\text { Hidar- } \\
\text { Megabit }\end{array}$ & $\begin{array}{l}\text { Ginbot- } \\
\text { Nehase }\end{array}$ & $\begin{array}{l}\text { Low and } \\
\text { mid land }\end{array}$ \\
\hline
\end{tabular}


Major diseases of barley include covered smut, loose smut, barley stripe, leaf rust, ergot, barley scald, bacterial blight, yellow rust, eye spot, septoria leaf blotch, common root rot, powdery mildew. Major Insect pests are barley fly, barley shoot fly, stink bugs, grass hoppers, armyworms, brown wheat mite, stem maggot, aphid. Lack of improved varieties, except (HB-

Table 6: Agronomic practices and farming system for tef.
1307) which is introduced by Arbaminch Agricultural Research Center through PED program and characterization of local genotypes. Barley growing areas include: Chencha, Bonke, Geze Gofa, Mello koza, Basketo special woreda , Oyda, Ubadebretseha, Kamba (Table 6).

\begin{tabular}{|c|c|c|c|c|c|}
\hline \multirow[t]{2}{*}{ Crop } & \multicolumn{2}{|r|}{ Cultivars } & \multicolumn{2}{|c|}{$\begin{array}{l}\text { Croppingcalendar (Including Land } \\
\text { Preparation) }\end{array}$} & \multirow[t]{2}{*}{ Agro Ecology } \\
\hline & Improved & Local & Belg & Meher & \\
\hline tef & $\begin{array}{l}\text { Kuncho and } \\
\text { CR-37 }\end{array}$ & $\begin{array}{c}\text { Sergegna, Key teff, asnakech, } \\
\text { ilga,bukula,tsama,jemisha,manize,dufa } \\
\text { uha, Dara, abi. }\end{array}$ & Tir-Megabit & $\begin{array}{c}\text { Gimbot- } \\
\text { Nehase(Gamo Gofa } \\
\text { and Basketo special } \\
\text { woreda while Hamile- } \\
\text { Tikimt for Segen area } \\
\text { people area zone }\end{array}$ & Low and mid land \\
\hline
\end{tabular}

Commonly used tillage frequency for tef in the study area ranges from 2-3 times within 15 days interval. Both broadcasting and row sowing method are common but dominated by broadcasting. Weeding frequency mostly conducted two times and weeding is done by both chemicals and hand. First weeding ranges from 15-20 days after sowing, second hand weeding two months after sowing. Diseases of tef include head smut where as locksets and birds are major Insects pests. Lack of improved varieties except Kuncho ( DZ-Cr-01-387) and DZ-Cr-37 (Tuesday), poor seed supply system, sterility problems, lack of low moisture stress resistant varieties, poor agronomic practices, time and rate of fertilizer application, seed rate, sowing method and existence of noxious weed (locally named as Asendabo) are major problems. Tef growing areas includes Konso, Derashe, Amaro ,Mirab Abaya, Melo koza, Demba Gofa, Boreda, Zala.

There are also other pulse, oil, fiber and horticultural crops that are common in the study area. Most common fiber crop is cotton. There is no improved varities introduced in the study area. It is produced in belg season starting from Hidar to Ginbot. Hand weeding is common and no chemical application is used. Boll-wilting and aborting is common in the study area. Lack of improved varieties (high yielding, disease resistant, poor agronomic practices (spacing, tillage frequency, seed rate, both time and rate of fertilizer application), lack of disease and pest controlling method, poor post-harvest handling and complicated marketing system, time of harvesting, poor storage system, lack of co-operative marketing center (price fixed by merchants/ traders) are some of identified problems in the area. Mirab abaya, Arbaminch zuria, Zala, Kamba, Derashe, Konso, and Basketo special woreda are common growers.

High land pulse crops which are grown in the study areas include; Chick pea (grown in Mirab abaya, Kucha, Derashe, Konso, Boreda while Faba bean and Field pea (grown in Chenach, Bonke, Mellokoza, Gezegofa and Kamba. Lack of improved varieties (lack of high yielding, diseases and pests), poor agronomic practice (sowing system, weeding system and frequency, time and rate of fertilizer application), lack of improved seed supply, lack of integrated pest management system are common for mentioned crops. Cropping calendar includes both belg (chick pea; Tir-megabit and meher Hamile-Tikimt) and meher (Faba bean and Field pea; Miyaziya-Sene). Low land pulse and oil crops include common bean, mungbean, ground nut and sesame. Mirab abaya, Kucha, Derashe, Konso, Boreda, Konso, Arbaminch zuria, DembaGofa, Zala are common growers. Lack of improved varieties, poor agronomic practices, lack of IPM, less attention from both producers and stakeholders and high market demand are action seeking issues.

Coffee and spices are also common in the study area. Coffee is cash crop especially in Melokoza, Geze Gofa, Basketo, Kamba, Bonke, Boreda, Arbaminch, Amaro,Derashe, Demba gofa,Oyda,Kucha. Lack of high yielding, diseases and pestresistant, low moisture resistant varieties, poor diseases controlling practices, poor IPM practice, poor harvesting and post harvest handling and lack of awareness on seed bed establishment are major gap of the production. Coriander (Kororima) is grown in Melokoza, Basketo, Gezegofa. No research has been conducted at all in the area so far, though the crops have high market and medicinal value.

Horticultural crops includes Potato (Improved Varieties includes; Tolcha, Menagesha, Degemegn, Belete, Jalene, Wechecha, Gudene; Local cultivar includes Asmera, kallessa (demo) and Etho), Cassava, Sweet potato and Taro. Lack of disease resistance variety, integrated pest management, Poor agronomic practice and land preparation, Poor post harvest handling and marketing system, lack of diffused light store (DLS), low price at harvesting time poor storage system, poor seed privation system, except VITA intervention kebeles, lack of disease free and quality seed, soil acidity problems are common in the study area. Chencha, Bonke, Kamba, Dita, Gezegofa, Mellokoza and Boreda are common growers.

Enset (local cultivars include Maze, Ganticho, Tsinke, Lofe, Masayiza, Bora, Zholola, Gena, Dengo, Aliga, Shana, Aginal, Masmaza, Amoza, Zinke, Chano, Bashira, Kafile, Falake,Wasaize, Swite, Bodh, Katise, Botsa, Choribo, Konka, Sorgale and Phiso). 
Collection and characterization, unavailability of effective Bacterial wilt control method, lack of awareness about bacterial wilt disease transmission and controlling mechanisms (e.g. common utilization of sharp tools), poor post harvest handling and marketing system (absence of clear marketing system), lack of improved varieties (for yield and disease resistance), poor agronomic practice were identified gaps for further research actions in the area. Amaro, Kamba, Melokoza, Gezegofa, Boreda, Oyda, Dembagofa, Ubadebretsehay, Deremalo, Basketo, chencha are common growers.

Commonly grown fruits include avocado (growers are Basketo, Mellekoza, Dembagofa and Kamba), Apple (growers are Chench, Bonke, Kamba, Boreda and Geze gofa), Banana (growers are Arbaminch, Mirab abaya, Ubadebretsehay, Demba gofa, Oyda. Kamba, Derashe, Amaro,Mellokoza and Basketo sepecial) woreda and Mango (growers includes Arbaminch, Mirab abaya, Ubadebretsehay, Demba gofa, Oyda. Kamba, Derashe, Amaro, Mellokoza and Kamba). Lack of improved varieties, lack of pest management, poor agronomic practices (like sucker management, spacing, cultivation), poor marketing system and post harvest handling and quality deteriorations are common.

Vegetables includes cabbage, Tomato, Onion, and Carrot are common in the area. Research seeking challenges include lack of improved verities (high yielding, insect and pest resistance verities ), poor agronomic practice (crop rotation, time and rate of fertilizer application), poor post harvest and marketing system, lack of cool storage, low price and intervention of breakers and absences of cooperatives.

Small scale Irrigation is common in the study area. Agricultural production system of Ethiopia is majorly based on rain fed. However, the fact is that in the many parts of Ethiopia the amount, frequency and distribution of rain fall is unpredictable and inadequate. Therefore, development of small scale irrigation could be taken as crucial alternative to alleviate the problem of crop production in the country. Total irrigation potential of Gamo Gofa, Segen area people Zones and Basketo special woreda is 74964.3731 ha, 23122 ha and 9168 ha respectively of which currently $60 \%$ is irrigated by using existing modern irrigation scheme, traditional river, spring and alternative technologies. However, irrigation had not contributed its share to the overall economical development of zone as required so far. Major crops produced under irrigation include:-Maize, sweet potato, banana, onion, cabbage, apple, coffee, carrot, mango, avocado, papaya, cassava and enset.
The major challenges and constraints facing for irrigated agriculture include inadequate emphasis given for setting up of appropriate institutional arrangements at all levels, limited trained manpower, Inadequate capacity and skills in the area of irrigation, inadequate, extension services and structure maintenance problem. In view of crops produced, farmers are not governed by a set of time scheduling. Shortage of alternative technologies (rope washer, geo membrane, motor pamper, treadle, drip...etc) supplies and lack of introducing water harvesting methods. Other challenges like lack of improved irrigation technologies (cropping calendar, planting and irrigation methods and rate, irrigation schedule, cropping pattern, weeding frequency), lack of irrigation agronomic practice, lack of attention for irrigation water quality, lack of on farm water and crop management, faulty and excess irrigation practices(simply water soil attachment rather than irrigation), poor priories for high value crop, lack of improved verities (high yielding, insect and pest resistance verities), poor quality seed supply, lack of attention from stalk holders especially from extension and research.

\section{Conclusion}

All mentioned challenges under each listed commodities are farmer's practices in the research mandate area that has not been resolved through research actions so far and needs research intervention either from regional, national or international research institutes for further improvement of agricultural system in the area. Priority for Agronomic practices, disease related challenges, and adaptation and demonstration of listed commodities for the area like maize, sorghum banana, mango, common bean, tef, sesame, enset, wheat, barley, mung bean, taro, millet and others need to be paid attention by respective sectors.

\section{References}

1. Kubayo KS (2009) Analysis of agricultural input supply system: the case of dale woreda, southern nations, nationalities and peoples' region. Haramaya University, Ethiopia, pp. 110.

2. Rahel Kassahun (2003) Ethiopia's recent growth performance: A survey of literature.

3. The state of food and agriculture.

4. Lodhi AHA (2008) World development report. Agriculture for Development, University of Toronto, Canada. 

(C) (i) This work is licensed under Creative DOI: 10.19080/ASM.2018.01.555553

\section{Your next submission with Juniper Publishers} will reach you the below assets

- Quality Editorial service

- Swift Peer Review

- Reprints availability

- E-prints Service

- Manuscript Podcast for convenient understanding

- Global attainment for your research

- Manuscript accessibility in different formats

( Pdf, E-pub, Full Text, Audio)

- Unceasing customer service

Track the below URL for one-step submission https://juniperpublishers.com/online-submission.php 